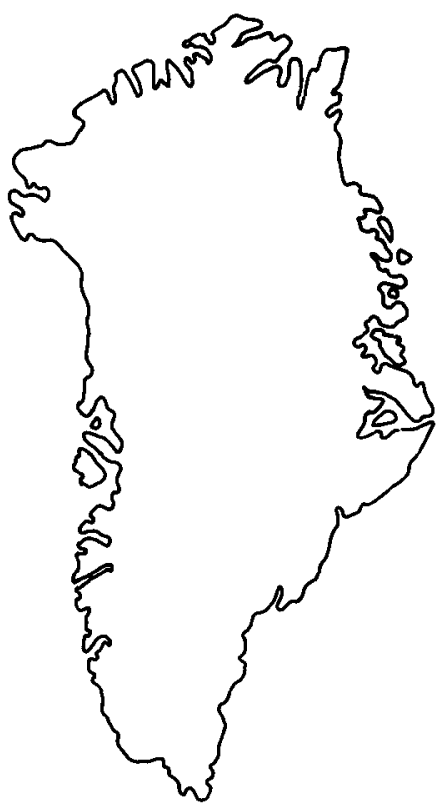

\title{
The Archaean Skjoldungen alkaline province, South-East Greenland
}

\author{
T. F. D. Nielsen and M. T. Rosing
}

\begin{abstract}
An alkaline province has been found to constitute a significant part of the Archaean terraines in the Skjoldungen area, $63^{\circ} \mathrm{N}$ in South-East Greenland. A total of twentyfour alkaline complexes and syenite gneiss areas has been identified. The alkaline magmatism is regarded as syn- to post-tectonic to judge from the wide variation in the degree of deformation. A large number of intrusions are virtually undeformed. Petrographically the province encompasses slightly $\mathrm{SiO}_{2}$-undersaturated mafic to $\mathrm{SiO}_{2}$-saturated syenitic rocks and a carbonatite-bearing nephelinitic complex. Neodymium-samarium model ages and a zircon age show the alkaline rocks to be c. $2800 \mathrm{Ma}$ old and the province thus constitutes the largest group of Archaean alkaline rocks yet found on Earth. The chemical characteristics, including very low concentrations of most trace elements except $\mathrm{Ba}$ and $\mathrm{Sr}$, recall those of the younger alkaline Seiland province in Norway and the Haliburton-Bancroft province in Canada.
\end{abstract}

T. F. D. N., Geological Survey of Greenland, Øster Voldgade 10, DK-1350 Copenhagen $K$, Denmark.

M. T. R., Geological Museum, Øster Voldgade 5-7, DK-1350 Copenhagen K, Denmark.

The Archaean terrains in South-East Greenland (fig. 1) can be divided into three areas: (1) a southern area dominated by granulite and amphibolite facies agmatitic gneisses; (2) a northern area dominated by non-agmatitic gneisses and supracrustal series mainly in amphibolite facies and (3) a central area transitional between (1) and (2), characterised by strong linear deformation and the occurrence of the alkaline rocks of the Skjoldungen alkaline province (Nielsen \& Escher, 1988; Rosing et al., 1988).

The central area is structurally dominated by a WNW-ESE deformation zone through the island Skjoldungen (Andrews et al., 1973). Areas with syenitic gneisses are found up to $70 \mathrm{~km}$ south of this zone, and the alkaline complexes have been observed up to $30 \mathrm{~km}$ south of the zone; no intrusions were observed north of the zone (fig. 2). The syenitic gneiss areas and intrusive complexes are deformed and foliated to variable extents and are thus syn- to post-tectonic. They are of such wide regional distribution and volumetric importance that it is appropriate to designate them as an alkaline province.

\section{The Skjoldungen alkaline province}

The Skjoldungen alkaline province is at present considered to include three areas of syenitic gneisses, twen- ty mafic to felsic $\mathrm{SiO}_{2}$-undersaturated to $\mathrm{SiO}_{2}$-saturated intrusive complexes, and an unknown number of granitic and/or syenitic intrusions in the Thrymheim area (fig. 2). The rocks of the province give rise to a major positive aeromagnetic anomaly in this part of Greenland (L. Thorning, personal communication, 1988).

The reconnaissance character of the investigations in South-East Greenland has not allowed detailed investigations and only some of the gneiss terrains and complexes listed below have been studied closely.

The observed and visited terrains and complexes are provisionally divided into six petrographic and geochemical groups (Table 1). It is emphasised that complexes denoted with (o) are virtually unknown and that many complexes may be much more complex than known at present, and may thus not be correctly classified. More syenitic gneiss terrains and complexes may occur in the province.

\section{Age of the Skjoldungen alkaline province}

Sm-Nd model ages (Kalsbeek, personal communication, 1988) show that all the investigated units are Archaean in age. These comprise basement gneisses, supracrustals, syenitic gneisses (no. 1, fig. 2), foliated and deformed gabbros and diorites (no. 4, fig. 2) and three of the alkaline complexes (nos. 6, 17 and 24, fig. 


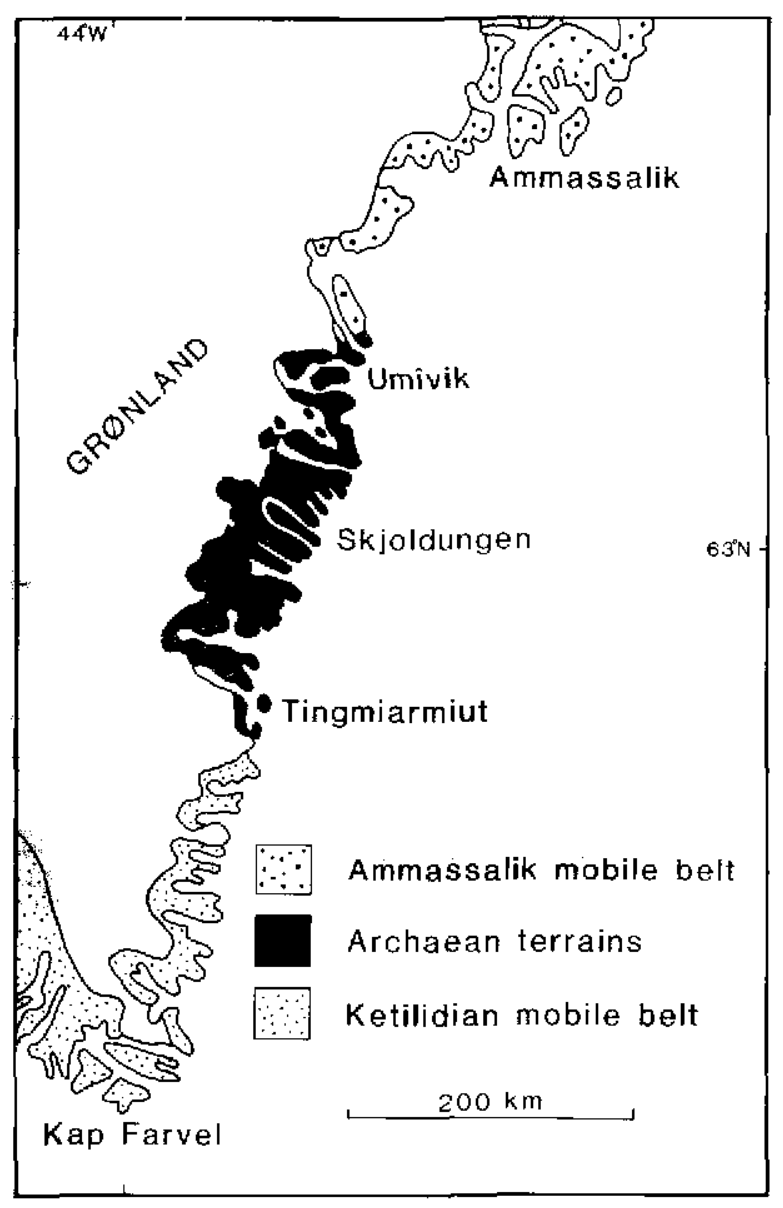

Fig. 1. The location of the Skjoldungen area in the centre of the Archaean terrains in South-East Greenland.

2). The ages calculated for the gneiss areas and intrusive complexes all cluster around $2800 \mathrm{Ma}$ (assuming a depleted mantle source). A more precise U-Pb age of 2680 Ma was obtained for the nephelinitic Singertât Complex (no. 24, fig. 2) from a single $12 \mathrm{~mm}$ zircon crystal (B. $\mathrm{T}$. Hansen, personal communication, 1988). It is thus clear that the Skjoldungen alkalinc province developed during and after a major metamorphic and tectonic event that probably peaked around $2800 \mathrm{Ma}$.

To the authors' knowledge only few alkaline complexes with similar ages have previously been reported world wide (e.g. Currie, 1976), but from nowhere else on Earth is a major Archacan alkaline province reported.

\section{Field characteristics and petrography}

Syenitic gneiss areas are readily recognised at a distance as large homogeneous light grey massifs characterised by extensive screes. The contacts of these gncisses to the surrounding agmatitic gneisses are always tectonic. However the syenitic gneiss areas form coherent sheetlike masses and are interpreted as deformed and folded intrusive bodies. They are intruded by few gently folded diorite dykes. Intense alkali feldspar mineralisation is observed on common horizontal fractures.

The syenitic gneisses are strongly dominated by perthitic alkali feldspar and may contain up to $10 \%$ quartz. None of the collected samples contain nepheline, and plagioclase is not a common phase. They contain minor green aegirinc-augite and/or green to bluish-green alkali amphibole and biotite. Sphene, opaque minerals and apatite are common accessory phases.

Foliated gabbros and diorites at locality 4 (fig. 1) form about 10 sheets, up to $50 \mathrm{~m}$ wide, of strongly foliated, medium to coarse grained rocks parallel with the WNW-ESE deformation zone along Skjoldungen. They are invariably broken up along their contacts and intruded by granitic veins (Nielsen et al., 1988a; Rosing et al., 1988).

The gabbros and diorites are plagioclase-rich orthopyroxene and amphibole-bearing plutonic rocks. Nepheline has not been observed. Alkali feldspar and biotite become increasingly important phases in the more evolved diorites of the suite. Apatite and opaque minerals are accessory phases.

Ultramafic, gabbroic and dioritic intrusive complexes. These complexes show variable degrees of deformation. The most well preserved complexes are virtually undeformed. A characteristic feature of many of these complexes is very well preserved modal layering as illustrated by Rosing et al. (1988). In several of the complexes repeated intrusion of mafic magma has resulted in brecciation and deformation of earlier gabbros and ultramafics.

Several of the complexes have marginal gabbros or horblendites with up to to $30 \mathrm{~cm}$ large poikilitic hornblende crystals perpendicular to the contacts in a matrix of hornblende, orthopyroxene, opaque minerals and apatite \pm plagioclase. The marginal zones are up to $5 \mathrm{~m}$ wide and givc way to laminated and layered gabbros, norites and syenogabbros. Biotite replaces hornblende and alkali feldspar becomes an increasingly important phase in the more evolved rocks of the complexes. In general, the mineralogy of these rocks is very similar to that of the foliated gabbros and diorites described above.

Dioritic to syenitic complexes. The two complexes in this group are both sampled in some detail and are virtually undeformed. The Sfinksen syenite complex (no. 17 in 
Table 1. Alkaline gneiss areas and intrusive complexes in South-East Greenland

Group Area/complex locality

1. Syenitic gneiss areas

$\begin{array}{ll}\text { Inner Kagssortoq } & 1(\mathrm{c}) \\ \text { Inner Kagssortoq } & 2(\mathrm{c}) \\ \text { Inner Sehested Fjord } & 3(\mathrm{o})\end{array}$

2. Foliated gabbros and diorites

Roar Halvø and Halvdan Fjord 4 (d)

3. Ultramafic, gabbroic and dioritic complexes

$\begin{array}{lr}\text { Vend Om Gabbro } & 5(\mathrm{~d}) \\ \text { Stærkodder Gabbro } & 6(\mathrm{~d}) \\ \text { Rumleren Ultramafic Centre } & 7(\mathrm{o}) \\ \text { Marie Dal Ultramafic Centre } & 8(\mathrm{c}) \\ \text { Thrym Gletscher Diorite } & 9(\mathrm{o}) \\ \text { Thrym Gletscher Gabbro } & 10(\mathrm{c}) \\ \text { Halvdan Fjord Gabbro and Diorite } & 11(\mathrm{c}) \\ \text { Hermod Vig Diorite 1 } & 12(\mathrm{o}) \\ \text { Hermod Vig Diorite 2 } & 13(\mathrm{o}) \\ \text { Thrymheim Ultramafic Complex } & 14(\mathrm{c}) \\ \text { Uivaq Diorite } & 15(\mathrm{c}) \\ \text { Sfinksen Diorite } & 16(\mathrm{c})\end{array}$

4. Dioritic to syenitic complexes

Sfinksen Syenite Complex 17 (c)

Ruinnæsset Intrusion 18 (d)

5. Felsic complexes

$\begin{array}{ll}\text { Thrymheim area (several) } & 19(0) \\ \text { Central Skjoldungen } & 20(0) \\ \text { Sfinksen Granite } & 21(0) \\ \text { Skinfaxe Gletscher Granite 1 } & 22(o) \\ \text { Skinfaxe Gletscher Granite 2 } & 23(0)\end{array}$

6. Strongly alkaline complexes

Singertât Complex

24 (d)

The number after each area or complex allows identification in fig. 2 , and the letters in parentheses indicate: $c$, confirmed; $o$, observed; d, detailed investigation.

fig. 2) is exposed in a steep mountain surrounded by glaciers, and the sheer walls show a major syenite pluton intruded into the Sfinksen diorite (no. 16, fig. 2). The syenites are in turn intruded by swarms of dolerite, andesite, syenite and granite dykes and veins. Some of the dykes are composed of basaltic to andesitic pillows chilled toward a syenitic matrix. The syenites and the dyke rocks were all collected from the glacier on the south side of Sfinksen peak. All the dyke samples were collected from dykes in large syenitic boulders.

The Ruinnæsset Intrusion (no. 18, fig. 2) is also vir- tually undeformed but has NW-SE oriented foliated dyke-like bodies interfingering with the basement gneisses at the WNW and ESE contacts. The marginal rocks are hornblende-bearing coarse grained gabbros. The main body of the intrusion shows a lateral and gradational transition from well layered biotite- and hornblende-bearing gabbros and monzogabbros in the east to biotite-bearing monzonites and syenites in the western part of the complex. Some of the more mafic parts of the complex are modally layered and contain apatite-magnetite layers up to $10 \mathrm{~cm}$ thick. 


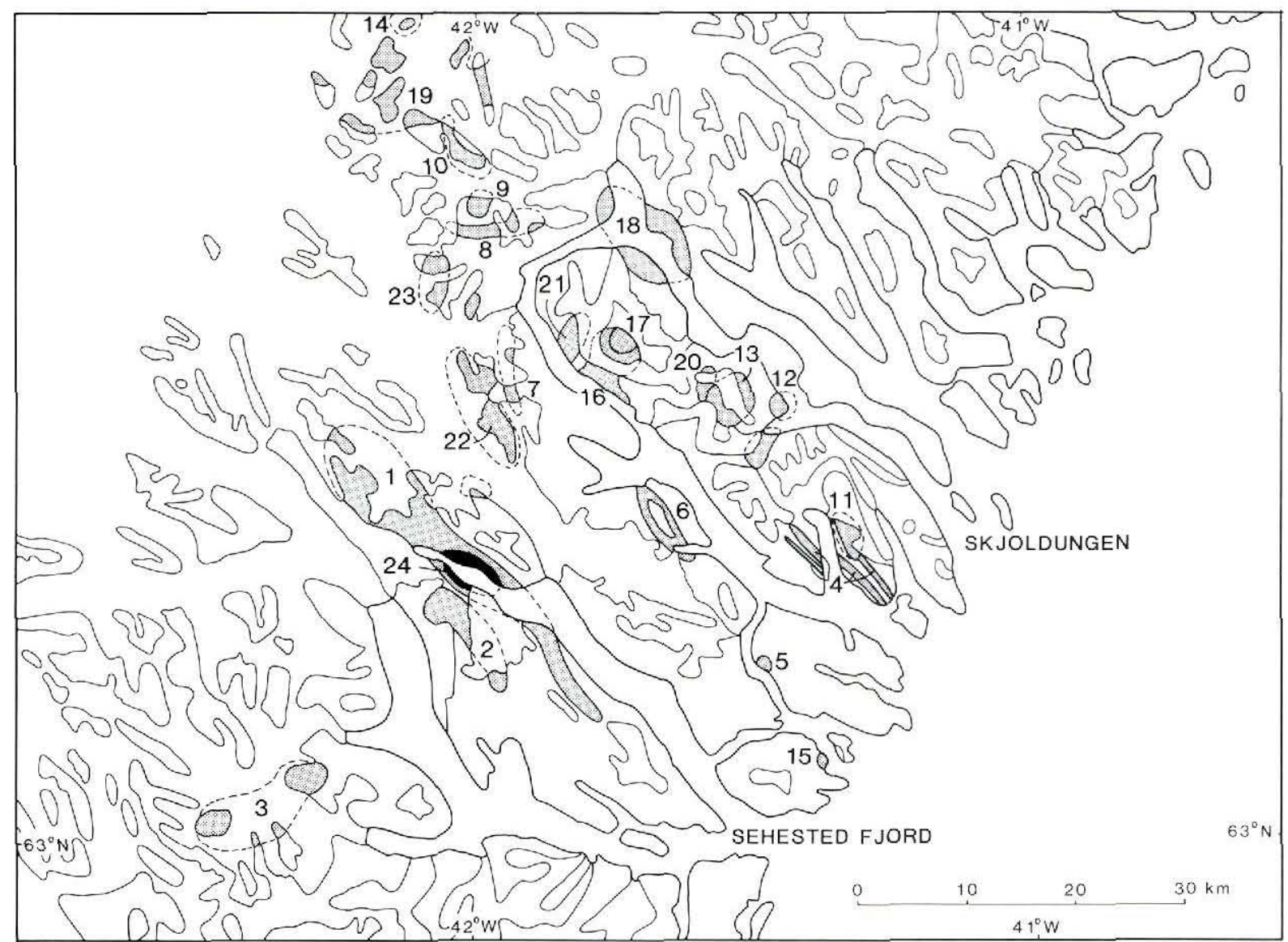

Fig. 2. The syenitic gneiss areas and intrusions of the Skjoldungen alkaline province. The numbers refer to the areas and intrusions identified in Table 1.

The mafic and intermediate rocks are composed mainly of plagioclase, amphibole and orthopyroxene and/or clinopyroxene, whereas the more felsic rocks are increasingly dominated by plagioclase, perthitic alkali feldspar and biotite. The syenites are nordmarkitic with up to a few per cent quartz in rocks strongly dominated by perthitic feldspar with minor alkali amphibole, aegirine-augite and biotite. Opaque minerals and apatite are common accessory phases in the mafic and intermediate rocks. Sphene is a common accessory in the more felsic rocks. In general, however, the rocks are poor in opaque minerals and apatite.

The felsic complexes have not been studied in any detail. The large plutonic masses constitute single nunataks and no intrusive contact has been observed between a major intrusive body and the surrounding gneisses. However, the same gneisses and earlier gabbros and diorites are in several localities heavily intruded by undeformed up to $10 \mathrm{~m}$ wide sheets of red syenites or granites.
A few samples, of which some are foliated, have been collected from the Thrymheim area (no. 19, fig. 2). They are dominated by alkali feldspar and contain up to $20 \%$ quartz and straddle the compositional boundary to granites. All of these felsic complexes are distinctly red to pink due to high contents of red alkali feldspar. They are easily identified from the air.

Ijolitic complex. The nephelinitic Singertât Complex at the head of Kagssortoq fjord covers an area of approximately $8 \mathrm{~km}^{2}$ of which only c. $1 \mathrm{~km}^{2}$ is exposed. The complex is emplaced into strongly fenitised granitic and agmatitic gneisses, which are often mineralised with siderite.

As also described from the Ruinnæsset Intrusion, foliated dyke-like bodies interfinger with the basement gneisses at the NW margin of the complex. This shows that the complex was emplaced during a late stage of the regional deformation. The plutonic core of the complex appears to consist of horizontal sheets of melteigite, ijolite and urtite. These plutonic rocks are equivalent to 
nephelinitic volcanic rocks and are composed mainly of clinopyroxene and/or amphibole and nepheline, often with minor but variable amounts of albitic plagioclase. The more mafic rocks are mostly biotite (phlogopite ?)-bearing. Apatite, opaque minerals and calcite are accessory phases. It is a characteristic that all phases tend to be anhedral. Alkali feldspar and plagioclase become important phases in the ijolites at the margins of the complex and in the dyke-like bodies at the NW margin. This is provisionally taken to indicate interaction with the surrounding fenitised basement.

The complex is intruded by a large variety of narrow $(<1 \mathrm{~m})$ nephelinitic to syenitic and carbonatitic dykes. The syenite dykes and veins are dominated by perthitic feldspar and contain variable amounts of nepheline, occasional blue cancrinite, alkali amphibole and/or alkali pyroxene, biotite, apatite and interstitial opaque minerals. The few but very impressive nepheline syenite pegmatites are composed of up to $20 \mathrm{~cm}$ large euhedral nepheline crystals and $10 \mathrm{~cm}$ large calcite crystals in an alkali feldspar matrix with veins and patches of opaque minerals.

Apatite-biotite søvite, apatite søvite and søvite dykes (generally less than $1 / 2 \mathrm{~m}$ wide) are not uncommon throughout the complex. Two dykes of inclusion-rich søvite were also noticed, and the inclusions include fragments of alkali feldspar crystals originating from the nepheline syenite pegmatites of the complex, and from basement xenoliths.

\section{Chemical characteristics}

Petrological and geochemical investigations have been initiated for several of the complexes of the prov-

Table 2. Mildly undersaturated to saturated rocks of the Skjoldungen Alkaline Province

\begin{tabular}{|c|c|c|c|c|c|c|c|c|c|c|}
\hline & 1 & 2 & 3 & 4 & 5 & 6 & 7 & 8 & 9 & 10 \\
\hline $\mathrm{SiO}_{2}$ & 45.75 & 46.37 & 48.21 & 51.20 & 53.16 & 58.80 & 59.16 & 61.22 & 61.14 & 72.36 \\
\hline $\mathrm{TiO}_{2}$ & 1.61 & 1.82 & 1.66 & 0.91 & 1.32 & 0.63 & 0.69 & 1.06 & 0.59 & 0.29 \\
\hline $\mathrm{Al}_{2} \mathrm{O}_{3}$ & 16.29 & 18.20 & 17.98 & 20.75 & 16.96 & 17.33 & 17.07 & 16.55 & 17.53 & 13.41 \\
\hline $\mathrm{Fe}_{2} \mathrm{O}_{3}$ & 2.67 & 5.22 & 4.57 & 2.43 & 3.61 & 2.70 & 2.36 & 1.40 & 1.94 & 0.90 \\
\hline $\mathrm{FeO}$ & 7.52 & 6.85 & 7.32 & 4.31 & 6.44 & 2.90 & 1.93 & 2.56 & 1.80 & 1.23 \\
\hline $\mathrm{MnO}$ & 0.18 & 0.15 & 0.19 & 0.08 & 0.19 & 0.09 & 0.07 & 0.11 & 0.06 & 0.02 \\
\hline $\mathrm{MgO}$ & 8.66 & 4.62 & 4.42 & 3.35 & 3.21 & 1.85 & 1.92 & 1.19 & 1.08 & 0.92 \\
\hline $\mathrm{CaO}$ & 8.90 & 8.23 & 7.15 & 8.64 & 4.74 & 3.21 & 5.78 & 2.72 & 2.51 & 1.09 \\
\hline $\mathrm{Na}_{2} \mathrm{O}$ & 3.61 & 3.57 & 5.16 & 4.67 & 5.77 & 7.32 & 4.66 & 4.96 & 6.80 & 2.61 \\
\hline $\mathrm{K}_{2} \mathrm{O}$ & 1.65 & 2.17 & 1.07 & 1.73 & 2.46 & 2.91 & 4.77 & 6.03 & 4.28 & 6.02 \\
\hline $\mathrm{P}_{2} \mathrm{O}_{5}$ & 0.08 & 0.97 & 0.84 & 0.57 & 0.73 & 0.66 & 0.53 & 1.00 & 0.33 & 0.02 \\
\hline \multirow[t]{2}{*}{ l.o.i. } & 2.61 & 1.02 & 1.89 & 0.97 & 1.70 & 0.94 & 0.40 & 0.32 & 0.68 & 0.62 \\
\hline & $\overline{99.52}$ & $\overline{99.19}$ & 100.45 & $\overline{99.64}$ & 100.29 & $\overline{99.33}$ & $\overline{99.34}$ & $\overline{99.12}$ & $\overline{99.05}$ & $\overline{98.79}$ \\
\hline ne $(Q)$ & 8.28 & 5.12 & 5.61 & 4.22 & 3.09 & 1.41 & - & 0.23 & - & (28.93) \\
\hline \multicolumn{11}{|c|}{ Reconnaissance trace elements (ppm) } \\
\hline $\mathrm{V}$ & 271 & 254 & 157 & 123 & 128 & 53 & 51 & 15 & 23 & n.d. \\
\hline $\mathrm{Cr}$ & 25 & n.d. & 11 & 6 & n.d. & n.d. & 10 & n.d. & n.d. & n.d. \\
\hline $\mathrm{Ni}$ & 84 & 27 & 1 & 37 & n.d. & 20 & 39 & n.d. & 19 & n.d. \\
\hline $\mathrm{Rb}$ & 38 & 66 & 15 & 49 & 32 & 45 & 62 & 30 & 46 & 86 \\
\hline $\mathrm{Sr}$ & 932 & 1170 & 1794 & 1199 & 666 & 630 & 2449 & 762 & 423 & 284 \\
\hline $\mathrm{Ba}$ & 863 & 1494 & 1151 & 1111 & 1357 & 1006 & 2923 & 2581 & 1016 & 784 \\
\hline $\mathrm{Zr}$ & 27 & 43 & n.d. & 57 & n.d. & 13 & n.d. & n.d. & 11 & n.d. \\
\hline $\mathrm{La}$ & 8 & 8 & 77 & 14 & 66 & 1 & 8 & 75 & 13 & 38 \\
\hline $\mathrm{Ce}$ & 39 & 56 & 224 & 41 & 226 & 37 & 67 & 197 & 29 & 130 \\
\hline $\mathbf{Y}$ & 24 & 27 & 21 & 23 & 22 & 14 & 16 & 10 & 11 & 4 \\
\hline
\end{tabular}

n.d.: not detected.

Detection limits in ppm. V: 15; Cr: 15; Ni: 5; Rb: 5; Sr: 5; Ba: 50; Zr: 10; La: 20; Ce: 20; Y: 2.

1: GGU 324769. Marginal gabbro, Ruinnæsset Intrusion.

2: GGU 311864. Foliated gabbro, Roar Halvø.

3: GGU 348061. Fine grained gabbro dyke, Sfinksen Syenite Complex.

4: GGU 311858. Foliated diorite, Roar Halvø.

5: GGU 348053. Diorite dyke. Sfinksen Syenite Complex.
6: GGU 324788. Margin of syenite dyke, Ruinnæsset Intrusion.

7: GGU 311838. Syenitic gneiss, Kong Dan Halvø, area no. 1 in fig. 2.

8: GGU 348050. Syenite, Sfinksen Syenite Complex.

9: GGU 324766. Syenite, Ruinnæsset Intrusion.

10: GGU 348068. Granitic dyke. Sfinksen Syenite Complex. 
ince, and samples from most of the visited complexes and syenitic gneiss areas have been analysed to ensure their chemical affinity to the alkaline province.

A suite of characteristic major and trace element compositions of the gabbros, diorites and syenites of the province and the syenitic gneisses and foliated gabbros and diorites are shown in Table 2. A suite af alkaline rocks from the nephelinitic Singertât complex is shown in Table 3.

A characteristic feature of all analysed rocks including weakly as well as strongly alkaline rocks is a strong and general depletion in all trace elements except $\mathrm{Ba}$ and $\mathrm{Sr}$. The low $\mathrm{Zr}$ and REE and the high $\mathrm{Ba}$ and $\mathrm{Sr}$ contents seem to be distinguishing features for the identification of the terrains and complexes of the Skjoldungen alkaline province. These features are also shown by the syenitic gneisses (Table 2, column 7) although the gneisses tend to have slightly higher $\mathrm{CaO}$ contents.

The chemical variation within the intrusive complexes is exemplified by the Sfinksen Syenite Complex (Table 2 nos $3,5,8,10$; fig. 3). The complex includes four separate groups of rocks, and this type of variation is observed in several complexes.

(1) Fine grained dolerites (with compositions similar to the fine grained gabbros of the province) are alkaline basalts with up to $5 \%$ normative nepheline. Some of these have accumulated apatite and opaque minerals.

(2) Andesites and diorites are either slightly nepheline normative or hypersthene normative.

(3) syenites (which have up to $12 \%$ total alkalies) are just saturated. They are very similar to syenites e.g. from the Ruinnasset Intrusion.

(4) granitic dykes and veins with up to $30 \%$ normative quartz.

The described systematic development from gabbros crystallised from alkali basaltic compositions to syenites of trachytic composition in the Ruinnæsset Intrusion suggests that the alkali basalt magmas fractionated towards trachytic compositions and that the apparent distribution in four separate groups (fig. 3 ) is the result of unrepresentative sampling.

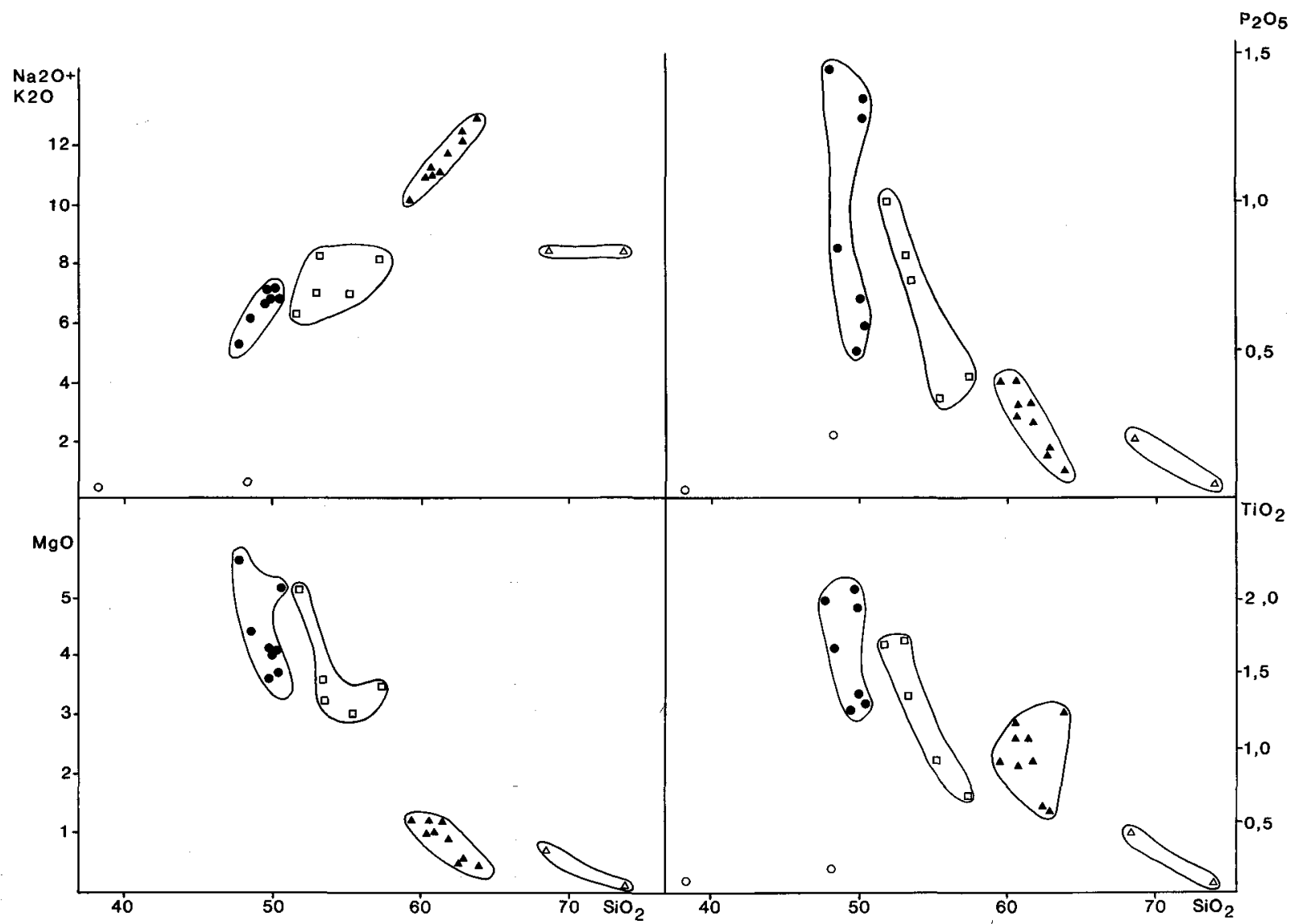

Fig. 3. The chemical variation in rocks from the Sfinksen Syenite Complex as illustrated by $\mathrm{Na}_{2} \mathrm{O}+\mathrm{K}_{2} \mathrm{O}, \mathrm{MgO}, \mathrm{P}_{2} \mathrm{O}_{5}$ and TiO $\mathrm{T}_{2}$ vs $\mathrm{SiO}_{2}$. Filled circles: dolerites and fine grained gabbros; open squares: andesites and diorites; filled triangles: syenites; open triangle: granites. 
Table 3. Nephelinitic rocks and carbonatites from the Singertât Complex

\begin{tabular}{|c|c|c|c|c|c|c|c|c|c|c|}
\hline 1 & 2 & 3 & 4 & 5 & 6 & 7 & 8 & 9 & 10 & \\
\hline $\mathrm{SiO}_{2}$ & 45.65 & 45.77 & 44.83 & 41.25 & 44.00 & 50.72 & 56.61 & 30.51 & 7.36 & 0.50 \\
\hline $\mathrm{TiO}_{2}$ & 0.71 & 0.50 & 0.89 & 0.32 & 0.18 & 0.31 & 0.71 & 0.26 & 0.31 & 0.00 \\
\hline $\mathrm{Al}_{2} \mathrm{O}_{3}$ & 13.91 & 15.96 & 20.24 & 14.92 & 25.28 & 21.03 & 17.12 & 12.00 & 2.82 & 0.06 \\
\hline $\mathrm{Fe}_{2} \mathrm{O}_{3}$ & 3.59 & 0.33 & 3.46 & 1.14 & 0.03 & 2.30 & 2.33 & 0.00 & 0.82 & 0.00 \\
\hline $\mathrm{FeO}$ & 4.42 & 6.27 & 6.03 & 3.30 & 2.58 & 2.05 & 1.90 & 2.97 & 2.88 & 0.99 \\
\hline $\mathrm{MnO}$ & 0.10 & 0.11 & 0.15 & 0.08 & 0.04 & 0.06 & 0.06 & 0.09 & 0.13 & 0.37 \\
\hline $\mathrm{MgO}$ & 10.08 & 8.24 & 3.53 & 3.50 & 1.81 & 2.54 & 2.19 & 2.49 & 2.98 & 1.44 \\
\hline $\mathrm{CaO}$ & 9.93 & 9.10 & 4.56 & 13.18 & 4.55 & 4.81 & 6.52 & 22.81 & 44.33 & 51.68 \\
\hline $\mathrm{Na}_{2} \mathrm{O}$ & 5.68 & 7.51 & 6.19 & 7.15 & 12.76 & 10.17 & 8.60 & 5.87 & 0.31 & 0.07 \\
\hline $\mathbf{K}_{2} \mathbf{O}$ & 3.75 & 3.61 & 4.23 & 3.00 & 4.34 & 3.64 & 1.64 & 2.52 & 1.70 & 0.03 \\
\hline $\mathrm{P}_{2} \mathrm{O}_{5}$ & 0.01 & 0.01 & 0.22 & 0.88 & 0.17 & 0.02 & 0.48 & 1.40 & 4.05 & 0.13 \\
\hline \multirow[t]{2}{*}{ 1.o.i. } & 1.96 & 2.52 & 4.02 & 9.46 & 3.17 & 1.67 & $\underline{0.95}$ & 17.42 & 30.54 & 42.24 \\
\hline & 99.79 & 99.94 & 98.36 & 99.94 & 98.89 & 99.31 & 99.11 & 98.34 & 98.30 & 98.26 \\
\hline ne & 26.61 & 33.95 & 25.15 & 33.95 & 58.58 & 38.92 & 12.28 & 18.32 & 1.46 & 0.08 \\
\hline \multicolumn{11}{|c|}{ Reconnaissance trace elements (ppm) } \\
\hline $\mathrm{V}$ & 118 & 83 & 94 & 58 & 32 & 69 & 55 & 35 & 17 & n.d. \\
\hline $\mathrm{Cr}$ & 176 & 111 & n.d. & n.d. & n.d. & n.d. & n.d. & n.d. & 38 & n.d. \\
\hline $\mathrm{Ni}$ & 117 & 74 & 26 & 27 & 19 & 25 & 21 & 42 & 36 & 9 \\
\hline $\mathbf{R b}$ & 68 & 63 & 184 & 59 & 39 & 38 & 17 & 55 & 38 & n.d \\
\hline $\mathrm{Sr}$ & 188 & 189 & 1727 & 966 & 461 & 785 & 1545 & 1461 & 4204 & 5176 \\
\hline $\mathbf{B a}$ & 574 & 360 & 1314 & 453 & 404 & 1347 & 1374 & 426 & 624 & 180 \\
\hline $\mathrm{Zr}$ & 101 & 111 & n.d. & 167 & 9 & 7 & 23 & n.d. & n.d. & n.d. \\
\hline $\mathbf{L a}$ & 9 & 4 & 13 & 27 & n.d. & 12 & 19 & 27 & 20 & 63 \\
\hline $\mathrm{Ce}$ & 31 & 6 & 44 & 42 & 12 & 19 & 49 & 93 & 215 & 231 \\
\hline $\mathrm{Y}$ & 12 & 12 & 16 & 22 & 7 & 8 & 8 & 38 & 65 & 51 \\
\hline
\end{tabular}

n.d.: not detected. Detection limits, see Table 2.

1: GGU 323689. $20 \mathrm{~cm}$ wide nephelinite dyke.

2: GGU 323605. $1 \mathrm{~m}$ wide nephelinite dyke.

3: GGU 323679. $20 \mathrm{~cm}$ wide calcite-bearing nephelinitic margin to urtite sheet.

4: GGU 323608. Fine grained calcite-rich ijolite, centre of complex.

5: GGU 323625. Urtite, sheet in centre of complex.

6: GGU 323696. $20 \mathrm{~cm}$ wide nephelinite dyke.

7: GGU 323699. Fenite, southern margin of complex.

8: GGU 323628. Inclusion-rich carbonatite dyke, centre of complex.

9: GGU 323631. Biotite- and apatite-rich søvite dyke, centre of complex.

10: GGU 323640. Søvite dyke, centre of complex.

The granitic rocks of the intrusive complexes have distinctly different and much lower alkali, $\mathrm{Ba}$ and $\mathrm{Sr}$ contents (Table 2 no. 10) and are, as suggested by the field observations in the Vend Om gabbro and in the foliated gabbroic to dioritic complexes, inferred to be anatectic melts derived from the enclosing basement (Rosing et al., 1988; Nielsen et al., 1988a).

The nephelinitic Singertât Complex is chemically distinct from all other intrusions of the province. The silicate rocks are strongly undersaturated (Table 3 ). The chemical variation (excluding carbonatites) is shown by the alkalies $v s \mathrm{SiO}_{2}$ diagram (fig. 4). The bulk of the melteigites, ijolites and urtites from the interior of the complex contain between 41 and $48 \% \mathrm{SiO}_{2}$ and the total alkalies vary between 9 and $17 \%$. This reflects mainly the variation in the proportions of alkali amphibole/ alkali pyroxene, nepheline and biotite in these cumulative rocks. The most silica-poor melteigites also contain calcite. The fine grained samples from nephelinitic dykes and margins of sheets possibly approach liquid compositions and have about $45 \% \mathrm{SiO}_{2}$ and $9-11 \%$ alkalies. All of these strongly alkaline rocks show the noted depletion in all trace elements except $\mathrm{Ba}$ and $\mathrm{Sr}$ characteristic of the province (Table 3 ).

The fenites from the contact aureole of the Singertât Complex include undersaturated as well as oversaturated felsic to mafic rocks. They are distinct from both the host gneisses and the alkaline rocks. 


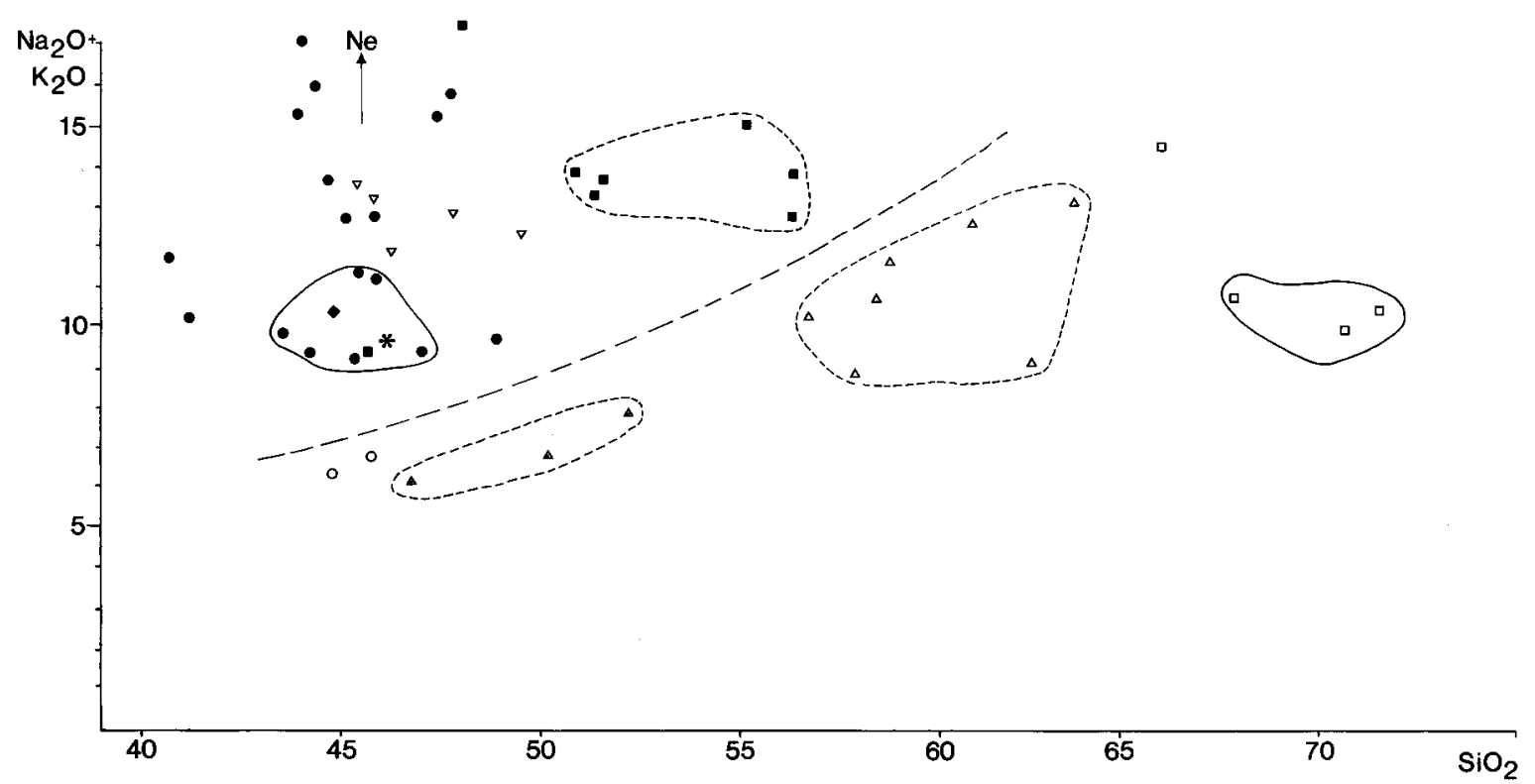

Fig. 4. The variation in the magmatic rocks and fenites of the Singertât Complex illustrated in the alkalis vs $\mathrm{SiO}_{2}$ diagram. Filled circles: melteigites, ijolites and urtites; filled squares: syenite dykes; inverted open triangles: plagioclase-bearing ijolites of marginal zones and dykes interfingering with basement; star: sulphide-rich ijolite; open circles: ultramafic rocks; filled triangles: fenitized basement amphibolites; open triangles: fenitized granitic basement rocks; open squares: rheomorphic contact granites. The stippled line separates the magmatic rocks from the fenites. Carbonatites are not included.

\section{Affinity of the Skjoldungen alkaline province}

The geochemical affinity of the province is very clearly shown by the trace element compositions (Tables 2 and 3). The notable depletion in most trace elements, except $\mathrm{Ba}$ and $\mathrm{Sr}$, in all the rock types of the province is characteristic for syn- to post-kinematic alkaline provinces such as the Caledonian Seiland province in Norway and the Proterozoic Haliburton-Bancroft province in Canada (Heier, 1965; Gerasimovsky, 1974). Both of these provinces are, as the Skjoldungen alkaline province, described as late to post-kinematic alkaline provinces.

In conclusion the Skjoldungen alkaline province is a major and probably the largest reported Archaean alkaline province on Earth. It is of a rare and uncommon type formed during the later stages of, or after, a major metamorphic and structural event. The Skjoldungen alkaline province should not be compared to modern rift related alkaline provinces.

\section{References}

Andrews, J. R., Bridgwater, D., Gormsen, K., Gulson, B., Keto, L. \& Watterson, J. 1973: The Precambrian of Southeast Greenland. In Park, R. G. \& Tarney, J. (edit.) The Precambrian of Scotland and related rocks of Greenland, 143-156. Birminghan University Press.

Currie, K. L. 1976: The alkaline rocks of Canada. Bull. geol. Surv. Canada 239, 228 pp.

Gerasimovsky, V. I. 1974: Trace elements in selected groups of alkaline rocks. In Sørensen, H. (edit.) The alkaline rocks, 402-411. London: Wiley and Sons.

Heier, K. S. 1965: A geochemical comparison of the Blue Mountain (Ontario, Canada) and Stjernöy (Finmark, North Norway) nepheline syenites. Norsk geol. Tidsskr. 45, 41-52.

Nielsen, T. F. D. \& Escher J. C. 1988: Reconnaissance investigations in the Skjoldungen region, South-East Greenland. Rapp. Grønlands geol. Unders. 140, 72-76.

Nielsen, T. F. D., Rosing, M. T. \& Vasudev, V. N. 1988a: Archaean gneisses of the Skjoldungen area, South-East Greenland. In Nielsen, T. F. D. (edit.) The Archaean terrains in South-East Greenland. Intern. GGU rep., 17-32.

Nielsen, T. F. D., Rosing, M. T. \& Vasudev, V. N. 1988b: The nephelinitic Singertât Complex. In Nielsen, T. F. D. (edit.) The Archaean terrains in South-East Greenland. Intern. GGU rep., 67-79.

Rosing, M. T., Nielsen, T. F. D. \& Vasudev, V. N. 1988: An alkaline igneous province in the Skjoldungen area, Southeast Greenland. In Nielsen, T. F. D. (edit.) The Archaean terrains in South-East Greenland. Intern. GGU rep., 55-66. 